\title{
ĐặC TRƯNG VĂN HÓA HÀN QUỐC QUA TỤC NGŨ CÓ YẾU TỐ CHỈ CON NGỰA
}

\author{
Hoàng Thị Yến* \\ Khoa Ngôn ngũ và Văn hóa Hàn Quốc, Truờng Đại học Ngoại ngũu, ĐHQGHN, \\ Phạm Văn Đồng, Cầu Giấy, Hà Nội, Việt Nam \\ Nhận bài ngày 21 tháng 03 năm 2018 \\ Chỉnh sửa ngày 28 tháng 05 năm 2018; Chấp nhận đăng ngày 29 tháng 05 năm 2018
}

Tóm tắt: Bài viết sử dụng phương pháp miêu tả kết hợp với các thao tác phân tích, tổng hợp với đối tượng nghiên cứu là 361 đơn vị tục ngữ tiếng Hàn có yếu tố chỉ con ngựa ${ }^{1}$. Hình ảnh con ngựa trong tục ngữ tiếng Hàn được khắc họa một cách chân thực và tượng trưng cho cuộc đời của một con người. Giá trị biểu trưng của các đơn vị tục ngữ tiếng Hàn có yếu tố chỉ con ngựa thể hiện ở việc đề cao những giá trị chân - thiện - mĩ, những bài học mang tính chất giáo huấn và chuyển tải kinh nghiệm phong phú về cuộc sống, quan hệ ứng xử. Giá trị đả kích và phê phán cái ác, mặt tiêu cực, châm biếm những thói hư tật xấu của con người cũng thể hiện rõ nét và sâu sắc. Cuộc sống vật chất và tinh thần, dấu ấn văn hóa thể hiện nhân sinh quan, thế giới quan của người Hàn hàm chứa đậm đặc trong tục ngữ có yếu tố chỉ con ngựa. Việc liên hệ với tục ngữ tiếng Việt có yếu tố chỉ ngựa cũng cho thấy có không ít những nét tương đồng trong ngôn ngữ và văn hóa của hai dân tộc.

Tù khóa: tục ngữ tiếng Hàn, con ngựa, giá trị biểu trưng

\section{Mở đầu}

Tục ngữ là đơn vị ngôn ngữ có phương thức biểu hiện giản dị, ẩn dụ và súc tích chứa đựng những chân lý về kinh nghiệm, trí tuệ mang mục đích giáo huấn của một dân tộc. Kết quả khảo sát cho thấy, ở Hàn Quốc, có khá nhiều công trình tiếng Hàn nghiên cứu về tục ngữ động vật nói chung, tiêu biểu như: tác giả Jang Jae Hwan (2009) tiến hành so sánh tục ngữ động vật trong tiếng Hàn, tiếng Nhật (trọng tâm là tục ngữ có yếu tố chỉ ngựa

\section{*ĐT: 84-972157070}

Email: hoangyen70@gmail.com

${ }^{1}$ Nghiên cứu này được tài trợ bởi Đại học Quốc gia Hà Nội trong đề tài mã số QG.18.21. Bài viết được hoàn thiện trên cơ sở tham luận tại Hội thảo Quốc gia Nghiên cúu và giảng dạy ngoại ngũu, ngôn ngũ và quốc tế học tại Việt Nam, tháng 4/2017, Trường Đại học Ngoại ngũ - ĐHQGHN. và chó). Tác giả Kim Myung Hwa (2011) nghiên cứu so sánh tục ngữ động vật 12 con giáp trong tiếng Hàn và tiếng Trung... Các công trình nghiên cứu đối chiếu về tục ngữ có yếu tố chỉ ngựa tiêu biểu có: tác giả Ho Nyung Nyung (2011) thực hiện nghiên cứu so sánh tục ngữ trong tiếng Hàn và tiếng Trung có yếu tố chỉ ngựa. Tác giả Byambachereng Battolga (2012) nghiên cứu so sánh tục ngữ Hàn Quốc và Mông cổ, tập trung vào tục ngữ yếu tố chỉ ngựa... Tại Việt Nam, gần đây có các nghiên cứu đối chiếu tục ngữ tiếng Hàn và tiếng Việt của Trần Văn Tiếng (2006); Nguyễn Thùy Dương (2013), Nguyễn Thị Hồng Hạnh (2013)... Các công trình nghiên cứu đối chiếu, so sánh hay liên hệ giữa tục ngữ động vật trong tiếng Hàn và tiếng Việt gần đây có: Lê Thị Thương (2009), Lê Thị Hương (2015), Hoàng Thị Yến và Nguyễn Thùy Dương (2016), 
Hoàng Thị Yến (2017)... Tuy nhiên, nghiên cứu một cách toàn diện về tục ngữ tiếng Hàn có yếu tố chỉ con ngựa trong mối liên hệ với tiếng Việt còn thiếu vắng. Hi vọng, bài viết sẽ góp phần lấp bớt khoảng trống này.

Trong văn hóa phương Đông, đặc biệt là các nước Trung Quốc, Nhật Bản, Hàn Quốc và Việt Nam, ngựa (ngọ) là một trong 12 con giáp. Chúng tôi thu thập được 361 đơn vị tục ngũ có yếu tố chỉ con ngựa xuất hiện trong công trình Tù điển tục ngũ động vật của tác giả Song Jae Seun (1997). Bài viết sử dụng phương pháp miêu tả nhằm làm rõ các đặc điểm ngữ nghĩa của các đơn vị tục ngữ tiếng Hàn có yếu tố chỉ con ngựa. Các thao tác khảo sát; dịch và phân tích thành tố nghĩa, thống kê, phân loại... cũng được áp dụng nhằm giải quyết các nhiệm vụ nghiên cứu sau: 1) Khắc họa hình ảnh con ngựa trong tục ngữ tiếng Hàn; 2) Phân tích giá trị biểu trưng của các đơn vị tục ngữ tiếng Hàn có yếu tố chỉ con ngựa; 3) Phân tích cuộc sống của người dân Hàn thể hiện qua tục ngữ. Chúng tôi cũng thực hiện thao tác liên hệ với tiếng Việt nhằm cố gắng phác thảo vài nét so sánh về văn hóa của hai dân tộc Hàn - Việt. Nguồn ngữ liệu tiếng Việt được lấy từ các công trình liên quan, tiêu biểu là Nguyễn Văn Nở (2008), Vũ Ngọc Phan (2008)...

\section{Hình ảnh ngựa trong tục ngữ tiếng Hàn}

Trong công trình của Song Jae Seun (1997), số lượng các đơn vị tục ngữ có yếu tố chỉ con ngựa là 361 đơn vị, đứng thứ tư sau tục ngữ chỉ con chó (986 đơn vị), bò (573 đơn vị), hổ (443 đơn vị). Điều này cho thấy, ngựa cũng là loài động vật gần gũi và có ảnh hưởng lớn đến đời sống vật chất và tinh thần của người Hàn. Tác giả Song Jae Seun (1997: 85-133) phân chia tục ngữ chỉ con ngựa thành các nhóm nhỏ như dưới đây:

\begin{tabular}{|c|c|c|c|c|c|c|c|}
\hline Yếu tố & $\begin{array}{c}\text { 말 } \\
\text { ngựa }\end{array}$ & $\begin{array}{c}\text { 망아지 } \\
\text { ngựa con }\end{array}$ & $\begin{array}{c}\text { 늙은 말 } \\
\text { ngựa già }\end{array}$ & $\begin{array}{c}\text { 천리마 } \\
\text { thiên lí mã }\end{array}$ & $\begin{array}{c}\text { 용마 } \\
\text { long mã }\end{array}$ & $\begin{array}{c}\text { 사나운 말 } \\
\text { ngựa dữ }\end{array}$ & $\begin{array}{c}\text { 여 윈 말 } \\
\text { ngựa gầy }\end{array}$ \\
\hline Tần số & 288 & 15 & 14 & 16 & 11 & 9 & 8 \\
\hline
\end{tabular}

Trong tục ngữ chỉ con ngựa, ngoài từ 말 mal (ngựa) còn có các yếu tố khác chỉ ngựa, ví dụ như: 준마 駿馬tuấn mã, 호마 胡馬 Hồ mã, ngựa nước Hồ... Ngoài ra, chúng ta thấy còn có 망아지ngựa con, 늙은 말 ngựa già, 사나운 말 ngựa dữ, 여윈 말 ngựa gầy ốm, 천리마thiên lí mã và 용마 long mã. Hình ảnh ngựa trong tục ngữ tiếng Hàn bộc lộ các đặc điểm về sinh lí và tập quán ăn uống... khá đa dạng khi xét theo các tiểu loại như sau:

\subsection{Hình ảnh ngụa nói chung}

Qua khảo sát, trong tục ngữ tiếng Hàn, các loại ngựa xuất hiện khá phong phú. Theo giới tính, ta có: 피마/ 암말 ngựa cái, 수말 ngựa đực... Theo màu sắc, ta có: 흰 말 ngựa trắng, 백마 bạch mã, 가라말/ 검은 말 ngựa đen...
Căn cứ vào tuổi ngựa, ta có: 갓난 말 ngựa mới sinh, 금승말 ngựa non (dưới 1 tuổi), 하룻망아지 ngựa sơ $\sinh$, 늙은 말/ 노마 ngựa già... Theo quan hệ huyết thống của cá thể ngựa, ta có: 어미 말 ngựa mẹ, 말새끼 ngựa con, 생마새끼 ngựa hoang con... Theo mục đích sử dụng, ta có: 역마 ngựa thồ, 파발마 ngựa đưa tin... Dựa vào sự sống chết của ngựa, ta có: 죽은 말 ngựa chết (tồn tại khoảng trống của 살아있는 말ngựa sống); theo môi trường sống, ta có 생마 ngựa hoang (tồn tại khoảng trống của 길들인 말ngựa nuôi, ngựa nhà). Theo giống loài, ta có các loài ngựa: 조랑말 tiểu mã, giống ngựa nhỏ, 호마 Hồ mã, ngựa Hồ, 준마 tuấn mã, 천리마 thiên lí mã, 용마 long mã..; theo quyền sở hữu, ta có: 삾말 ngựa thuê, ngựa trạm ... 
Về đặc điểm sinh lí, các bộ phận cơ thể của ngựa có: 말굽 móng ngựa, 꼬리 đuôi, 말고기 thịt ngựa, 말귀 tai ngựa, 말다리/ 말발 chân ngựa, 말 대가리/ 말머리 đầu ngựa, 말등 lưng ngựa, 말뼈 xương ngựa, 말살 thịt ngựa, 말상 mặt ngựa, 털 lông, 말갈기bờm ngựa, 말배bụng ngựa, 말가죽 da ngựa... Về các chất bài tiết của ngựa, ta có: 말똥 phân ngựa, 말이 방귀를 뀌다 ngựa đánh rắm... Theo đặc điểm hình thức của ngựa, ta có: 큰 말 ngựa to, 작은 말 ngựa nhỏ, 애꾸말 ngựa chột mắt, 살찐 말ngựa béo, 마른 말 ngựa gầy, 여윈 말 ngựa gầy ốm, 날개 달린 말 ngựa có cánh = 천리마 thiên lí mã, 네 발 가진 말 ngựa có bốn chân, 눈 먼 말 ngựa mù, 저는 말/ 절뚝발이 말 ngựa què...; 말이 울다 ngựa khóc = ngựa hí...; 말냄새 mùi ngựa...

Về đặc điểm tập tính, hành động, theo các vật dụng thường dùng được gắn vào mình ngựa, ta có: 고삐를 놓은 말ngựa tháo cương, 고삐없는 말/ 굴레없는 말 ngựa không cương, 굴레 씨운 말ngựa đeo cương, 말채 roi ngựa, 재갈 hàm thiếc... Ngoài ra còn có: 수레 xe ngựa, 길마 gùi hàng, 안장/ 언치yên ngựa... Theo trạng thái, sức khỏe của ngựa, có các biểu hiện như: 굶주린 말 ngựa đói, 상사말 ngựa động đực, 밤 눈 어둔 말 ngựa không nhìn thấy trong bóng tối, 배 않는 말 ngựa bị đau bụng... Theo sự di chuyển và cách thức di chuyển của ngựa, ta có: 가는 말 ngựa đi, 넘어지는 말 ngựa ngã, 놓아 먹인 말 ngựa thả rông, 달리는 말/ 말이 뛰다 ngựa chạy/ ngựa phi, 빠른 말 ngựa nhanh... Liên quan đến nơi ở của ngựa, ta có: 마방 chuồng ngựa, 말뚝 cọc buộc ngựa, 기둥 cột, 마굿간 chuồng ngựa... Về tập tính ăn uống và thức ăn của ngựa, ta có: 말이 콩을 그리 워하다 ngựa nhớ đỗ/ đậu, 목 마른 말 ngựa khát nước, 여물 rơm cỏ khô, ...소금을 먹는 말 ngựa ăn muối... Tính cách và giá trị của ngựa thể hiện trong tục ngữ khá phong phú: 게으른 말 ngựa lười, 둔한 말 ngựa ngu, 못난 말 ngựa xấu, 못된 말 ngựa dở, 무는 말 ngựa hay cắn,
차는 말 ngựa háu đá, 여윈 말 ngựa ốm yếu/ bệnh tật, 사라운 말 ngựa dữ, 좋은 말 ngựa tốt, 센 말 ngựa khỏe, 약한 말 ngựa yếu...; 말은 바람을 좋아한다 ngựa thích gió, 말은 세워서 기른다 đứng nuôi ngựa, 값싼 말 ngựa rẻ...; 말의 힘 sức ngựa...

\subsection{Hình ảnh ngụa con}

Ngựa con 망아지xuất hiện trong tục ngữ giống như những đứa trẻ. Chúng được ngựa mẹ sinh ra: 말 씹으로 빠진 것은 다 망아지다 rơi ra tù âm hộ ngưa đều là ngựa con. Lúc thì chúng là những con ngựa con ghẻ lở, ốm yếu 비루먹는 망아지 trong lữ quán tồi tàn, khi lại tung tăng là những chú ngựa được tháo dây cương고삐 풀린 망아지/ 굴레 벗는 망아지..., có chú ngựa con côi cút, lang thang 놓아 기른 망아지 hay ngựa hoang con 생마새끼, có chú ngựa con mù 눈 먼 망아지 đi theo tiếng chuông, có chú ngựa con ngơ ngác, lạc mẹ giữa bầy 뗏말에 망아지...

\subsection{Hình ảnh ngụa già}

Ngựa già 늙은 말 cũng giống như người cao tuổi, có những hạn chế của tuổi cao sức yếu nhưng lại có cái trải đời, hiểu biết và kinh nghiệm: 늙은 말은 길을 잃지 않는다 ngụa già không lạc đưòng, 늙은 말은 짐작으로 길을 안다ngưa già có thể định huoóng tìm đuoòng, 늙은 말의 지혜다trí tuẹ của ngưa già... Vốn thích đỗ, ngựa già cũng không chê đố 늙은 말은 콩은 마다 않는다, thậm chí có phần hơi tham lam: ngựa già đòi thêm đỗ 늙은 말이 콩 더 달란다. Tuy nhiên, 젊어서 잘 뛰던 말도 늙으면 못 뛴다nguxa già không thể chay nhu thuở trẻ, 늙으면 용마도 삾말보다도 못한다già thi long mã cũng không bằng ngựa trạm cho thuê...

\subsection{Hình ảnh ngụa dũ}

Ngựa dữ 사나운 말 cũng như kẻ bất trị, phá phách, tính cách hung dữ. 사나운 말은 
물고 찬다 ngụa dũ cắn và đá, 사나운 말이 말뚝이 상한다 ngưa dũ làm hỏng cọc buọc. Để trị ngựa dữ, dân tộc Hàn có khá nhiều biện pháp hay, ví như: 사나운 말에 지우는 길마는 따로 있다 với ngưa dúu, có gùi thồ hàng riêng; 사나운 말에는 무거운 길마 지운다chất hàng nặng cho ngựa dũu, 사나운 말은 고삐와 채찍으로 길 들인다 dùng dây cuơng và roi để trị ngưa dũ , dùng roi vọt để sửa đổi, uốn nắn tật xấn. Con người, nếu không chịu sửa mình, thì khó có thể tự do: 사나운 말 재갈 떠날 날 없다 ngưa dũ không có ngày tháo bỏ hàm thiếc... Tuy nhiên, cũng như người Việt coi ngựa chúng là ngựa hay, người Hàn có câu: 사나운 말이 천리 간다 ngưa dũ đi ngàn dặm: Đôi khi, người hung dữ cũng giống như ngựa dữ, là người có sức khỏe tốt, làm việc hăng hái, rất hiệu quả, học cũng có thể làm những việc lớn, phi thường...

\subsection{Hình ảnh thiên lí mã}

Thiên lí mã là ngựa hay, ngựa tốt. 천리마는 날마다 천리를 뛴다Thien li $m \tilde{a}$ mỗi ngày có thể đi ngàn dặm. Tuy nhiên, người Hàn quan niệm: Một con ngựa muốn trở thành thiên lí mã, ngoài tư chất bẩm sinh khác thường, cần có những điều kiện như: Phải đến độ tuổi nào đó mới có thể thành tựu được (cần thời gian): 천리마는 나이가 들어서 이루어진다 phải có tuổi mói thành thiên lí $m \tilde{a}$; phải có môi trường đủ rộng lớn mới có thể huấn luyện, trưởng thành được (cần giáo dục tốt): 천리마는 뜰 안에서 길 들일 수 없다 không thể thành thiên lí mã trên cánh đồng được: Môi trường của thiên lí mã phải là thảo nguyên bao la, rộng lớn... Thiên lí mã là ngựa hay, chứ không phải ngựa thần, có sức mạnh siêu nhiên, vì thế: 천리마도 단번에 열 발자국은 못 뛴다 thiên lí mã không có nghĩa là mối lần nhảy là nhảy được 10 buớc, 천리마라고 단번에 뛰어 천리를 가는 것은 아니다 thiên li mã không phải là một lần nhảy có thể đi ngàn dặm: Về đại thể, thiên lí mã cũng bình thường như bao con ngựa khác, vì thế, mỗi lần nhảy chỉ có thể nhảy một sải chân... Khi về già, thiên lí mã hay hồi tuơơng về thời huy hoàng có thể đi ngàn dặm 천리마는 늙었어도 천리 가던 생각만 한다thien $l i$ $m a \tilde{~ g i a ̀ ~ c u ̃ n g ~ c h i ~ n g u ̉ ~ ㄴ ㅡ ㄺ ㅇ ㅡ ㄴ ~ ㅊ ㅓ ㄴ ㄹ ㅣ ㅁ ㅏ ㄱ ㅏ ~ ㅈ ㅏ ㅁ ㅁ ㅏ ㄴ ~}$ 잔다. Nếu không gặp được thời vận, thiên tài cũng chỉ là người bình thường chết già nơi xóm vắng, phố thưa. 천리마가 마굿간에서 늙는다 thiên li mã già trong chuồng ngụa. Người Việt quan niệm: người tài nhiều tật. Người Hàn cũng không thiên vị và chỉ ra: 천리마에도 못 된 버릇이 있다 thiên li $m \tilde{a}$ cũng có tật xấu của nó...

\subsection{Hìn ảnh long $m \tilde{a}$}

Long mã là giống ngựa quí nên 말이 천 마리면 용마가 하나 있다ngàn con ngưa mói có môt long $m \tilde{a}$, 말도 용마라면 좋아하고 소도 대우라면 좋아한다 ngura thi thich long $m a \tilde{a}$ bò thì thích bò mộng. Cuộc đời mỗi con người, lịch sử mỗi gia tộc hay một đất nước... đều biến đổi thăng trầm theo qui luật: 되는 집은 말을 낳아도 용마만 낳는다 nhà phát đạt thì có ngưa đẻ cũng đẻ ra long mã: Nếu đang ở vận tốt thì mọi việc đều diễn ra tốt đẹp. Tục ngữ Hàn nhấn mạnh đến yếu tố cần yếu để sự vật hiện tượng có bước nhảy vọt về chất: 용마도 장수를 만나야 하늘을 난다 long mã phải gặp tuớng giỏi mói bay lên trời được, 용마도 주인을 못 만나면 삾말로 늙는다 long mã không gặp chủ thì chết già nhu ngựa thuê: Với long mã, yếu tố để tạo thành cặp là gặp được người chủ là tướng giỏi, kị sĩ tài ba..., khi đó, long mã mới có thể phát huy sức mạnh, có thể bay lên trời như rồng. Giống như hai mặt của một vấn đề, như âm với dương, người Hàn cho rằng: 장수 나면 용마 난다 nếu có tướng giỏi sẽ có long mã...

\subsection{Hình ảnh ngụa gầy}

Ngựa gầy ốm có các đặc điểm riêng, dễ nhận thấy, ví như: đuôi dài: 마른 말 꼬리가 
길다/ 여윈 말이 꼬리는 길다 ngụa gầy thi đuôi dài; hay có nhiều ruồi muỗi bám theo: 여윈 말에 파리 덤비듯 한다 nhu ruồi tấn công ngựa gầy... Ngựa gầy mà lại chất nhiều đồ trông rất đáng thương: 마른 말에 짐 많이 싣는다 chất nhiều đồ lên ngưa gầy...

Hình ảnh ngựa trong tục ngữ tiếng Hàn cũng gần gũi như các giai đoạn cuộc đời một con người, có sinh, lão, bệnh, tử; có thời vận thăng trầm, cần bí quyết và hội đủ các điều kiện mới có thể thành công... Với vài nét phác họa hình ảnh của ngựa con, ngựa già, ngựa gầy, ngựa dữ, thiên lí mã hay long mã trong tục ngữ, có thể thấy dân tộc Hàn có cái nhìn đa chiều, khá toàn diện và sâu sắc về cuộc sống của con người.

\section{Giá trị giáo huấn - truyền kinh nghiệm và giá trị phê phán, châm biếm của tục ngữ tiếng Hàn có yếu tố chỉ ngựa}

2.1. Giá trị giáo huấn - truyền kinh nghiệm, cảnh báo

\subsubsection{Giá trị giáo huấn - truyền kinh nghiệm}

\section{Về quan điểm giáo duc}

Tục ngữ tiếng Hàn có yếu tố chỉ con ngựa hàm chứa giá trị giáo huấn - truyền kinh nghiệm khá phong phú và sâu sắc. Khi ca ngợi những người tài giỏi khác thường, người Hàn ví với hình ảnh ngựa chạy nhanh lại có thêm đôi cánh có thể bay được: 날개 달린 말이다 nhu ngưa thêm cánh; ca ngợi các anh hùng chinh phục thiên hạ, tạo lập quốc gia bằng hình ảnh đầy khí thế, hào hùng: 말 타고 천하를 얻는다 cuơoi ngựa giành thiên hạ; ca ngợi phẩm chất, khí tiết vững vàng của bậc quân tử trong khó khăn bằng hình ảnh 저는 말도 길은 바로 간다 ngưa què vẫn đi đúng đường, con người dù có rơi vào hoàn cảnh nào cũng không nhụt chí, kiên trì nỗ lực sẽ thành công: 절뚝발이 말이 천리를 간다 ngụa què vẫn đi ngàn dạmm. Dân tộc Hàn coi trọng gia đình, quê hương bản quán: 말은 마방으로 가야 한다 ngưa phải về chuồng ngưa, đề cao sự rõ ràng, sòng phẳng trong giao dịch, xử thế: 말이 먹은 물 값도 준다 trả tiền nước ngưa đã uống. Trong thành ngũ̃, tục ngũ̃ Việt, câu môt con ngựa đau cả tàu bỏ cỏ ca ngợi tình đoàn kết, tương thân, tương ái giữa con người với con người; hình ảnh khuyển mã chi tình ca ngợi sự gắn bó, tình nghĩa, trung thành; câu thẳng nhu ruột ngựa nói về tính cách thẳng thắn, bộc trực của con người...

Giá trị giáo huấn thường truyền tải các bài học làm người, khuyên răn con người hướng tới giá trị chân - thiện - mỹ. Con người cần tự lập, chăm chỉ làm việc kiếm sống bởi lao động giúp loài người tiến hóa, giúp con người lương thiện: 굽 쳐먹는 말이라 hãy là con ngựa biết dùng móng bới đất tìm thức ăn, cho dù làm không tốt nhưng nếu chúng ta kiên trì, nhẫn nại, vẫn có thể hoàn thành công việc, đạt mục đích: 둔한 말도 열흘 가면 천리를 간다 ngưa dỏ đi 10 ngày cũng được ngàn dặm, không nên kén việc tốt hay xấu, việc gì cũng làm: 말 갈 데 소 갈 떼 가리지 않는다 không kén chọn nơ ngụa đi hay bò đi. Tục ngữ Hàn thể hiện quan điểm đánh giá con người không thể chỉ xét bề ngoài: Khi nhận định, đánh giá về đối tượng nào đó, ta cần qua thử thách, thận trọng, bởi vì: 털만 보고는 말 좋은 줄 모른다 chỉ nhìn lông không thể biết được ngựa tốt. Nếu chỉ đơn thuần 털 보고 말 고르기다 nhìn lông chọn ngưa, có thể sẽ phạm sai lầm. Nếu như người Việt có câu: Đường dài mới hay súc ngựa thì người Hàn cũng vậy: 말은 먼길을 타봐야 힘을 안다 đương xa mói biết súc ngưa, 길이 멀면 말의 힘을 알고, 날이 오래면 사람의 마음을 안다 đưòng dài mói biết súc ngưa, ngày dài mới biết lòng người. Khi đánh giá con người, ta cần nhìn qua hành động, chứ không đơn thuần là nghe lời nói hay. Cùng biểu đạt về quan điểm này, tục ngữ Hàn có các đơn vị sau: 말갈기가 외로 질지 바로 질지는 
봐야 안다 ngưa cày tốt hay dỏ phải thư móti biết, 내 말이 좋으니 네 말이 좋으니 해도 타봐야 안다 ngưa tôi tốt, ngựa anh tốt phải cuỡi thư mói biết. 여물을 많이 먹은 말은 똥을 줄 때 안다 ngưa ăn nhiều cỏ, khixem phân sẽ biết...

Thông qua việc đánh giá ngựa, chọn và mua ngựa, nuôi ngựa, tục ngữ Hàn chứa đựng nhiều kinh nghiệm quí giá trong giáo dục, dạy dỗ thế hệ tương lai. Thông thường, chúng ta thường thấy hai tai ngựa dựng lên làm thành hình chũ̃ $\mathrm{V}$, nhưng nếu 말 귀가 위로 쫑긋하면 성미가 급하다 tai ngưa dụng đúng là ngựa dũ. Từ việc quan sát đặc điểm ngựa, người Hàn khái quát thành kết luận sau: 말은 마르면 털이 길어지고 사람은 가난하면 무식해진다 ngưa gầy thì lông dài, nguời nghèo thì vô hoc. Bên cạnh đó, cũng như người Việt coi của rẻ là của ôi, tiền nào của ấy, người Hàn cho rằng đồ rẻ thì chất lượng không ra gì: 값싼 말은 이도 들쳐보지 말랬다 ngưa rẻ, răng cũng không nhìn. Khi đi chợ, nếu muốn biết thời giá của mặt hàng nào đó, nên hỏi giá của vật/ hàng hóa gần với nó: 말 값을 알려면 먼저 개값을 물어보랬다 muốn biết giá ngưa, hãy hỏi giá chó. Một số kinh nghiệm khác liên quan đến việc mua bán, giao dịch cũng khá thú vị, ví nhu: 말 난 장에 소도 난다 chơ ngưa tất có bò: Bò và ngựa thường gắn với nhau, nên có cái này, tất có cái kia; 말 많은 데서 말 못 고른다 nhiều ngụa khó chọn: Vì thế, cần hết sức thận trọng mới mua được ngựa hay; kinh nghiệm chọn ngựa của người Hàn: 말을 살 때는 어미 말을 보고 사랬다 mua ngưa phải nhìn ngưa $m e ̣$ : Nhìn bố mẹ sẽ biết con cái. Người Việt cũng nhấn mạnh yếu tố di truyền trong quan niệm của mình bằng các hình ảnh như: $H o$ nhà tông không giống lông, giống cánh. giỏ nhà ai quai nhà nấy... Tập tính ăn uống của động vật thể hiện qua câu 물 마다는 말 없고 여물 마다는 소 없다 không có ngưa chê nước, không có bò chê cỏ: Cũng như vậy, con người có những điều yêu thích riêng. Khi dạy người cũng như khi rèn ngựa, người Hàn cho rằng, cần tùy đặc điểm của mỗi đối tượng để có biện pháp xử lí thích hợp: 좋은 말은 한 번 채찍질하면 그만이다 với ngưa tốt, chi cần thúc một lần là đủ, với người ngoan/ thông minh, nói một lần là nghe/ là làm tốt. Thông thường, người ít học không thể làm việc độc lập, tự mình tìm tòi khám phá nhưng có thể dê̂ dàng bắt chước người khác: 눈 먼 말이 워낭 소리 듣고 따라간다 ngưa mù đi theo tiếng chuông, cái khó khăn của việc dùng người mà không có điều kiện hay phương tiện khống chế được coi là 굴레 없는 말 몰기다 khó nhu điều khiến ngựa mà không có dây cuơng. Với những đối tượng đặc biệt, con người ra cần có cách xử trí đặc biệt, phải biết lựa tính cách để giao việc thì mới có hiệu quả: 말은 끌어야 잘 가고, 소는 몰아야 잘 간다 $n g u a$ phải kéo mới đi, bò phải đẩy mói đi. Đôi khi cũng phải dùng biện pháp cứng rắn, mang tính chất cưỡng chế, ví như: 말 약 먹이듯 한다 nhu cho ngựa uống thuốc...

Trong giáo dục con người, từ xưa, dân tộc Hàn đã ý thức được vai trò quan trọng của yếu tố xã hội: 금승말 갈기가 외로 갈지 바로 갈지 모른다 ngưa non 1 tuổi khi cày ruộng không biết sẽ đi lệch luống hay đi đúng huớng: Điều này không thể biết trước được vì tùy thuộc vào việc di chuyển của ngựa hay hướng gió thổi. Con người lớn lên cũng vậy, trở thành người tốt hay xấu tùy thuộc vào ý thức và bản lĩnh của cá nhân, ảnh hưởng và tác động của xã hội, con người cần môi trường xã hội và giáo dục tốt để phát triển, cũng như ngựa cần môi trường tự nhiên để lớn lên khỏe mạnh: 말새끼는 시골로 보내고 사람 새끼는 서울로 보내라 ngưa con gưi về nông thôn, trẻ con gửi lên Seoul. Về việc sử dụng bạo lực trong giáo dục, qua hành động dùng roi thúc ngựa, tục ngữ thể hiện quan niệm của người Hàn khá đa dạng. Bên cạnh ý kiến cho rằng: 가는 말에도 채찍을 치랬다 ngưa đang đi 
cũng quất roi thúc, 닫는 말에도 채질하랬다 ngựa đang chạy, khi cần cũng cần quất roi thúc: Ngựa là con vật, phải dùng roi vọt để dạy bảo, rèn tập. Tuy nhiên, việc làm này đôi khi lại phản tác dụng: 가는 말에 채질하면 똥만 싼다 ngưa đang đi quất roi thúc thi chi có vãi cứt. Khi ngựa đói, chúng sẽ không sợ roi: 굶주린 말이 채질을 두러워할까? ngụa đói biết sợ roi sao? Hơn nữa, năng lực/ khả năng mỗi cá thể là có hạn, không thể đòi hỏi quá đáng: 닫는 말 채질한다고 경상도를 당일 갈까? thúc ngưa đang phi hết sức liệu quất roi có đến được Gyeongsangdo trong ngày không? Khi giáo dục con người hay lãnh đạo một tập thể, ta cần có một sự linh hoạt, tùy cơ ứng biến cho phù hợp để đạt hiệu quả cao...

Quan điểm về ý thức trách nhiệm của người Hàn cũng được thể hiện một phần trong tục ngữ chỉ ngựa. Con người sống, cần có cách đối nhân xử thế hợp tình, hợp lí, có trách nhiệm: 말은 빌려도 꼴 값은 말 빌린 사람이 낸다 mươn ngưa thì người mươn trả giá mươn, người mượn cần biết điều, trả cho người chủ ngựa chi phí trong thời gian mượn, ai làm sai thì tự chịu trách nhiệm, phải tìm cách khắc phục hậu quả: 말 잃은 놈은 말 찾고, 소 잃은 놈은 소 찾는다 nguời mất ngưa thì tìm ngưa, người mất bò thì tìm bò. Trong cuộc sống, mỗi người đều có những nhu cầu khác nhau, cần biết ứng xử phù hợp, tránh có những hành động không phù hợp với hoàn cảnh, thân phận của mình, dễ thất bại và phải chịu sự phê phán, chê cười của người đời, ví như: 말 탄 거지다 ngườ ăn xin curơi ngụa...

\section{Về bi quyết thành công}

Việc thành công hay thất bại trong cuộc sống của con người tùy thuộc vào nhiều yếu tố. Người Hàn khuyên chúng ta phải luôn cân nhắc kĩ trước khi hành động: Đối với người có hình dạng và hành động khác thường, tốt nhất là đừng đôi co, dính dáng: 꼴 같잖은 말은
이도 들쳐보지 말랬다 ngưa không ra ngưa thì răng cũng không nên nhòm; có những việc mình tin là an toàn, ổn định nhưng cũng có khi thất bại, vì thế, phải cẩn thận, không được chủ quan: 네 발 가진 말도 넘어질 때가 있다 ngựa bốn chân cũng có khi ngãa; nếu cần thì: 다리 건너갈 때는 말에서 내린다 đi qua cầu phải xuống ngựa, 말 병은 사람 병 같이 약을 써야 한다 bệnh ngưa cunng phải dùng thuốc nhur người... Người Hàn cho rằng, bí quyết thành công là trước khi làm việc gì cũng phải kiểm tra tính khả thi của công việc, xem việc chuẩn bị đã hoàn tất chưa: 말 맬 말뚝이냐, 말을 못 맬 말뚝이댜? coc buôc được hay cọc không buộc được ngưa?: trước khi buộc ngựa, phải kiểm tra xem cọc có chắc chắn không? Bên cạnh đó, cần sáng suốt ý thức là việc gì cũng có thời điểm của nó, cần thời gian thích hợp để thực hiện, không nên nóng vội: 원님 말을 빌려도 사흔은 탄다 mươn ngụa của quan cũng phải cữoi 3 ngày... Bên cạnh đó, cũng cần phải xem xét lợi hại, tính khả thi trước khi làm bất cứ việc gì: 대감 죽은 데는 안 가도, 대감 말 죽은 데는 간다 quan chết không tới, ngựa nhà quan chết phải tới. Quan chết có thể đến chậm hoặc không đến nhưng ngựa nhà quan chết không tới sẽ mắc tội hỗn láo, không nể mặt quan. 대감 집 말 죽은 데는 먹던 밥도 밀쳐 놓고 가도, 대감이 죽었다면 먹던 밥도 다 먹고 간다 nghe tin ngựa nhà quan chết, bỏ dỏ bát com mà đi, nghe tin quan chết, ăn xong bũa corm $m o ̛ ́ i$ đi: Cũng bởi, khi còn quyền thế thì người đời vì sợ nên theo bám, khi không còn, người đời không sợ nữa, cũng vì không có tình cảm nên xa lánh...

Theo người Hàn, người lãnh đạo cần biết khai thác đúng sở trường, dùng người đúng việc: 쥐 잡는 데는 천리마가 고양이만 못한다 bắt chuột thì ngựa thiên lí mã không bà̀ng con mèo. 말에 짐을 무겁게 실으면 걷지를 못 한다 chất nạng ngưa không thể đi được: việc gì không phù hợp có thể gây 
tác động ngược. Điều khiển ngựa hay dùng người là cả một nghệ thuật: 차는 말도 타는 사람에게 달렸다 ngưa háu đá hay không cũng tùy người cuỡi... Sự nhanh nhạy, thường xuyên thay đổi sẽ có thể giúp thay đổi tâm trang: 말도 갈아타야 새맛이다 ngura phải đổi mới thấy thú vui mới: Không nên chỉ cưỡi mãi một con ngựa, việc đổi ngựa mới tốt hơn so với việc cứ cưỡi mãi một con ngựa. Trong cuộc sống, tình cảm con người là tự nguyện, có thể ép được thân xác, không ép được lòng người. Quan điểm này thể hiện qua câu: 말은 물가로 끌고 갈 수 있어도 물을 먹이지는 못 한다 lôi được ngựa đến mép nước, không ép được ngựa uống nước. Cách dùng người được người Hàn đúc kết một cách súc tích như sau: 말은 상등 말을 타고 소는 중등 소를 부리고 사람은 하등 사람을 부리랬다 $c u \tilde{o} i$ ngựa thượng đẳng, nuôi bò trung đẳng, dùng nguời ha đẳng: Cưỡi ngựa tốt mới đi được nhanh, bò bình thường dễ uốn nắn, người ngu dốt dễ sai bảo, cai trị... Tục ngữ tiếng Hàn có yếu tố chỉ ngựa cũng chuyển tải một thông điệp: Cần có cái nhìn người sáng suốt bởi bản tính con người khó đổi: 무는 말은 죽어야 안 문다 ngưa dũ hay cắn thì phải chết mói hết cắn. Người ác thì chết mới đổi được bản chất ác, đừng nên hi vọng sẽ thay đổi được ai đó, thay vào đó, chúng ta cần thay đổi, điều chỉnh bản thân mình để có thể thích ứng với môi trường, các mối quan hệ và sống tốt. Thế gian rộng lớn, xã hội phức tạp: 무는 말이 있으면 차는 말도 있다 có ngưa hay cắn thi cũng có ngụa hay đá. Con người cũng vậy, mỗi người mỗi tính, muôn người muôn vẻ... Người Việt có câu: Ngựa chạy có bầy, chim bay có bạn răn dạy con người sống phải hòa đồng với tập thể, thể hiện rõ văn hóa cộng đồng của cư dân vùng lúa nước. Qua tục ngữ, người Hàn cũng chia sẻ một số kinh nghiệm nhìn ngựa, biết người như: 말과 말이 만나면 서로 찬다 ngựa gạp ngựa sẽ đá nhau: Câu này hàm ý mấy thanh niên ngổ ngáo gặp nhau là đánh nhau; khi không tỉnh táo, con người khó có thể phân biệt chính xác sự việc: 말 똥이 밤알같이 보인다 trông phân ngựa nhu hạt dẻ; bản chất và bản tính của con người luôn bộc lộ tự nhiên, không thể che giấu, cũng nhu: 말은 노상 뛸 생각만 한다 ngua chi nghĩ đến chạy trên đường; người lo việc lớn thì không để ý việc nhỏ: 말은 기르는 사람은 닭, 돼지를 돌보지 않는다 nguời nuôi ngưa không thể chăm gà lợn... Trong tiếng Việt có câu nguu tầm nguu, mã tầm mã: Muốn biết ai đó là người thế nào, chỉ cần xem anh ta đánh bạn với ai. Đây cũng là triết lí phổ biến của nhiều dân tộc trên thế giới... Người Hàn khuyên người đời sau nên cẩn thận với người đời, thậm chí với cả những người xung quanh, gần gũi: 상전이 말은 믿고 살아도 종은 믿고 못 산다 ngườ trên tin ngưa nhung không tin người hầu: Ngựa là con vật trung thành, khi cưỡi có thể tin tưởng được, người hầu hay nịnh, không thật lòng, tuy sống gần nhưng không thể tin được.

Người Hàn tin rằng, dù có nhiều hạn chế, điều kiện dù thiếu thốn, khó khăn nhưng nếu con người nỗ lực, vẫn có thể thành công: 둔할 말이 열 수레를 끈다 ngụa dỏ cũng kéo được 10 cái cày, 말똥을 놓아도 손맛에 달렸다고 dù có cho phân ngựa thì cũng tùy thuộc vào tài nấu ăn. Khi làm việc phải kiên trì thử nghiệm, làm nhiều lần mới có kết quả hoàn chỉnh: 말똥도 세 번 굴러야 제자리에 선다 phân ngựa cũng phải lăn ba vòng mói đứng lạ; yếu tố năng lực cũng luôn được đề cao: 말이 좋아야 무거운 짐을 싣는다 $n g u a$ tốt mới có thể thồ hàng nặng: Người có sức mạnh mới đảm nhận được việc lớn; sự đầu tư cũng là yếu tố quan trọng: 말 잡은 집에 소금 헤프다 nhà bắt ngưa, phung phi muối: Nếu giết ngựa nhà mình sẽ cần dùng nhiều muối... Trong cuộc sống, nếu con người có chiến lược khôn khéo, biết dựa vào người có thế lực, có thể lợi dụng sức mạnh đó để tiến thân một cách dễ dàng, cũng như: 말 꼬리에 붙은 
파리가 천리를 간다 ruồi đậu đuôi ngựa đi

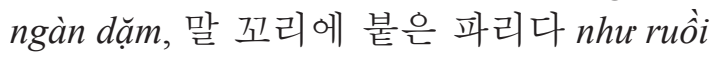
đậu đuôi ngựa; biết lựa chọn sáng suốt để thu lợi lớn nhất: 말은 백마를 기르고 소는 검은 소를 기르랬다ngưa thì nuôi bach mã , bò thì nuôi bò đen: Bạch mã là giống ngựa tốt, bò đen thịt ngon, cày khỏe; biết triển khai công việc theo trình tự hợp lí, trúng tâm điểm, đúng mấu chốt... sẽ mang lại thành công: 말 탄 사람을 쏘려면 먼저 말을 쏘아야 한다 nếu định bắn người cữơi ngựa thì phải bắn ngụa truớc. Cũng như người Việt quan niệm: có thực móri vưc được đạo, người Hàn cũng nhấn mạnh tầm quan trọng của yếu tố vật chất: 먹지 않고 잘 걷는 말 없다 không có ngưa không ăn gì mà chayy tốt. Trong cuộc sống, muốn thành công, cần có mục đích, lí tưởng rõ ràng để có động lực phấn đấu đến cùng, tuy nhiên, cần đặt ra các mục tiêu cụ thể, ngắn hạn để phấn đấu, tránh hiện tượng 먼산 보고 달리는 말은 지쳐죽는다 ngưa chay nhì núi xa sẽ mỏi mệt mà chết ...

\subsubsection{Giá trị cảnh báo}

Trong thực tế, tác động của môi trường đối với con người là vô cùng to lớn: Các cá thể cùng sống trong một môi trường thì dễ bị ảnh hưởng lẫn nhau: 말이 미치면 소도 미친다 ngựa điên thi bò cũng điên; nếu có người hiệu triệu, tất sẽ có người hô ứng: 말이 울면 다른 말도 따라 운다 môt con ngưa hí thì con khác cũng hí theo... Để cảnh báo nguy hiểm hay hậu quả xấu, tục ngữ Hàn có nhiều hình ảnh, ví nhu: 눈 먼 말 타고 벼랑을 간다 cuõoi ngưa $m u ̀$ đi vách đá; 장님 눈 먼 말 탄 격이다 $n h u$ người mù cữoi ngựa mù; con người mắc lỗi lầm không chỉ hại bản thân, sự nghiệp chung cũng chịu ảnh hưởng: 넘어지는 망이 수레 부순다 ngụa ngã xe đổ. Trong xử thế, không nên dồn người khác vào đường cùng vì 말은 궁하면 방탕하다 ngựa vào đưòng cùng cũng bỏ chủ mà đi, vì người vào thế cùng dễ mất bản tính vốn có: 말 제 고삐 뜯어먹는
격이다 như ngưa cắn dứt dây cưong. Chúng ta nên tránh xa những nơi nguy hiểm cũng như 말은 변두리로 가지 않는다 ngưa không $\mathrm{ra}$ bia rìng. Con người phải cẩn thận, không chủ quan cậy tài, cậy giỏi, vì nếu sơ sẩy một chút, có thể nguy hiểm đến tính mạng: 말 잘 타는 사람은 떨어져 죽는다 người cuỡi ngưa giỏi ngã ngưa mà chết. Trong một gia đình, một cơ quan, một quốc gia, cần tạo nên sự thống nhất quyền lực mới có thể phát triển: 말 대가리가 둘이면 가지 못한다 ngụa có hai đầu không di đurơc...

\subsection{Giá trị phê phán, châm biếm}

\subsubsection{Giá trị phê phán}

Giá trị phê phán thể hiện thái độ dứt khoát, rõ ràng của người dân Hàn đối với áp bức, bất công trong xã hội, đối với những thói xấu hại người của con người. Ở mức độ cao, tục ngữ ngựa lên án âm mưu của kẻ xấu, ví như hành động phá hoại hoa màu của người khác: 고추밭에 말달리기 xua ngựa chay ruộng ót; trộm hoặc chiếm đoạt của cải của dân: 말 탄 양반 청태 도적이라 qui tộc cuõi ngụa trộm rong biển... Sự bất công trong xã hội được phản ánh rõ nét trong tục ngữ: Người làm quần quật, vất vả nhưng thành quả và sự đãi ngộ thì người khác hưởng: 뛰기는 역마가 뛰고 먹기는 파발꾼이 먹는다 ngưa tram chay, nguời cuơoi ăn, 뛰기는 파발마가 뛰고 먹기는 돼지가 먹는다 ngưa đura tin chay, lọn thì ăn... Với ý nghĩa tương tự, người Việt có câu: cốc mò cò xơi... Qua tục ngữ, người Hàn cũng tỏ rõ thái độ đối với thói giả dối của những con người mặt người nhưng dạ thú: 말과 원숭이의 마음씨다 lòng da ngưa và khi; phê phán hành vi buôn gian bán lận: 양 대가리 걸어 놓고 말 고기 판다 treo đầu dê bán thịt ngưa. Tiếng Việt có câu thành ngữ: đầu trâu, mặt ngựa để chỉ và phê phán phường trộm cướp, gian ác...

Trong tục ngữ tiếng Hàn có yếu tố chỉ con ngựa, nội dung phê phán thái độ làm việc thiếu 
cân nhắc, suy xét, không có kế hoạch... thể hiện khá đa dạng, ví như: 갓난 말에 큰 길마 지운다 chất hàng lớn lên ngưa non; ý tưởng ngu ngốc và hành động khó chấp nhận được: 말 등에 실었던 짐을 벼룩 등에 싣는다 hàng chất lưng ngưa mà mang chất lên lung con bo chét... Trong thực tế, nếu không biết tự lượng sức mình, con người dễ mù quáng và thực hiện hành động ngu ngốc 둔한 말이 열 수레를 끈다ngưa dơ đòi kéo 10 cái cày. Người ngu dốt nhưng lại đòi nhận việc quan trọng, không lường hết hậu quả tồi tệ có thể xảy ra: 말 똥도 모르고 마의 노릇만 한다 phân ngưa cũng không biết mà đòi làm mã $y$... Những việc làm không đúng lúc, không kịp thời do thiếu tầm nhìn, không biết lo xa cũng bị hai dân tộc phê phán gay gắt: 말 잃고 마굿간 고친다 mất bò mói lo làm chuồng. Việc xét đoán công việc, xét đoán sự việc sai có thể dẫn đến hành động không đúng đắn, gây hậu quả khó lường: 배 않는 말 머리들기다 chũa đầu cho ngựa bị đau bụng. Việc tính toán thiếu sáng suốt dễ dẫn đến gây thiệt hại hoặc làm việc kém hiệu quả: 제 주에 말 사놓은 격이다 mua ngưa sã̃n ỏ Cheju: Việc mua nhiều ngựa để tích trữ, đầu cơ ở một nơi nhiều ngựa như Cheju là thiếu sáng suốt...

Người Hàn cũng phê phán thói ỷ lại, không dựa vào sức mình của một bộ phận người dân: 걸어가다가도 말만 보면 타고 가잔다 đang đi bộ, thấy ngựa là đòi cuõoi; phê phán thói lười biếng, không biết tự lượng sức mình, định làm một lần cho xong việc: 게으른 말이 짐 탐낸다 ngưa luoòi tham hàng; phê phán thái độ làm việc đại khái, mang tính hình thức, qua loa: 달리는 말 타고 꽃 구경하기다 cuoơi ngưa xem hoa hay: 달리는 말 타고 산 구경하기다cuõi ngưa ngắm núi; phê phán cách kết hợp không phù hợp, đúng cách: 말대가리에 쇠뿔이다 sùng bò ở đầu ngựa, 말에 뿔이다 cắm sùng cho ngụa. Khi phê phán những người có cá tính mờ nhạt, thái độ không rõ ràng, người Hàn dùng hình ảnh: 말도 아니고 노새도 아니다 chẳng phải ngựa, cũng chẳng phải la trong khi người Việt dùng hình ảnh dơ ông dỏ thằng. Đối với lời nói thiếu nhất quán, không liên quan hoặc khác nhau về bản chất, người Hàn liên tưởng tới hai động vật gần gũi là bò và ngựa: 말살에 쇠뼈다 xương bò thịt ngựa, 말살에 쇠살이다 thịt bò thit ngưa...

Thái độ trọng danh vọng, tham lợi ích của người đời cũng là đối tượng phê phán của tục ngữ. Đối với lòng tham vô hạn của con người, người Việt dùng câu được voi đòi tiên, người Hàn dùng hình ảnh: 말 타면 경마를 잡히고 싶다 được cuõ̃i ngụa lại muốn bắt ngụa đua, 말 타면 종 두고 싶다 cuõoi ngưa rồi muốn thêm người theo hầu; lên án thói đời đen bạc: 말 죽은 밭에 까마귀 모이듯 한다 qua tu ruộng có ngựa chết: chỗ nào có lợi quyền là lũ trục lợi bu đến; phê phán những người thợ chejangsu vô tình, chỉ quan tâm đến lông đuôi ngựa dùng làm nguyên liệu dùng cho công việc của mình: 금산 체장수는 말 꼬리부터 만져본다 thơ chejangsu Geumsan sò̀ tù đuô $n g w a$, 금산 체장수 말 죽기만 기다린다 tho' chejangsu Geumsan đợi ngựa chết; phê phán sự ích kỉ: 내말 맨 다음에 아버지 말 맨다 buộc ngựa mình rồi mới buộc ngựa cho cha. Thậm chí, có người vì lợi ích của mình mà làm hại người khác, gây khó khăn cho công việc của người khác: 남의 말에 안장 지운다 tháo yên ngựa của người khác, kể cả khi đối tượng bị hại là họ hàng thân thích, gần gũi: 삼촌 말 먼저 잡고 내 말 잡는다 bắt ngụa của cậu trước rồi mói đến ngựa mình...

Nội dung phê phán cách hành xử, ăn nói chưa chuẩn mực, đúng đắn... của một bộ phận người dân cũng được phản ánh trong tục ngũ̃. Đặc biệt là phê phán những người thiếu hiểu biết, vô phép tắc: 놓아 먹인 말이다 nhu ngưa thả rông; phê phán người có hành động quá khích: 물고 차는 상사말이다 (lồng lên như) ngưa động đực cắn rồi đá; phê phán cách ăn nói hồ đồ: 삼년 묵은 말가죽이 들을 달린다 
da ngụa ba năm chạy ra đồng: Ý nói lời nói vớ vẩn, hoang đường, không chấp nhận được. Thái độ vô ơn, vô tình vô nghĩa, thói thay lòng đổi dạ, thay đổi thái độ một cách chóng mặt bị người Hàn phê phán gay gắt: 말고기 먹고 말 씹내난다고 한다 ăn thịt ngụa xong lại chêcó mùi khai, 말 한 마리 다 먹고 비린내 난다고 한다 ăn hết con ngựa rồi chê mùi thịt ngụa tanh. Người Hàn cũng tỏ rõ quan điểm trước thái độ bàng quan, vô tâm của con người: 말귀에 동풍이 스치듯 한다nhu gió đông thổ $i$ vào tai ngụa; phê phán người chịu ơn nhưng lại lấy oán báo ơn: 제가 기른 말에 게 채인다 bị ngựa mình nuôi đá; thói đời cá lón nuốt cá $b e ́$, kẻ mạnh bắt nạt kẻ yếu thế: 파리도 여윈 말에 붙는다 ruồi bám ngưa gầy yếu... Người Việt có các câu ngựa non háu đá phê phán thói ngông cuồng, quá khích, nông nổi của tuổi trẻ; câu ngựa quen đường cũ phê phán những người lầm đường lạc lối thiếu bản lĩnh, không đủ ý chí chiến thắng bản thân để hoàn lương, chứng nào tật nấy, câu ngựa lồng cóc cũng lồng phê phán sự máy móc, học đòi, bắt chước thiếu chủ định, sáng suốt của người đời...

\subsubsection{Giá trị châm biếm, trào phúng}

Tiếng cười trào phúng của người Hàn thể hiện qua tục ngữ có yếu tố chỉ ngựa khá phong phú, thường ít nhiều pha chút ý phê phán nhưng nhìn chung chỉ dừng lại ở mức độ giễu cợt, chê cười đối với hình thức xấu xí, sự ngây dại... của người đời. Về hình thức, người Hàn châm biếm người có gương mặt chỗ xanh chỗ đỏ: 곽란에 죽은 말 상이다 (xanh, đỏ) $n h u$ mặt ngựa chết vì bệnh tả; chế giễu người say rượu, mặt đỏ: 말고기 자반이다 đỏ $n h u$ thịt $n g u ̛ a$, 말고기 좌판이다 đỏ $n h u$ bàn bán thịt ngụa; cười người to lớn, mặt trắng trẻo, công tử bột: 센 말 볼기짝 같다 (bầu bĩnh, phúng phính) nhu má ngụa khỏe, cười cái ngây ngô của người đời: 말과 사슴을 분별 못 한다 không phân biệt được ngựa với hươ; chê cười một hành động ngốc ngếch: 죽은 말 한 마리에 산 말 한 마리다 so môt con ngưa sống với một con ngụa chết; cười người không biết tự lượng sức mình: 여 윈 말이 짐 탐낸다 ngụa gầy tham đồ; chê những người nhạt nhẽo, vô vị: 설삶은 말 대가리 같다 $n h u$ đầu ngựa luộc dối. Khi châm biếm hành động thiếu tỉnh táo, ngẩn ngơ của con người, người Hàn dùng hình ảnh: 말 타고 말 찾는다 cuõoi ngựa lại đi tìm ngựa. Châm biếm tình huống dở khóc dở cười khi không có được đầy đủ cả hai thứ vốn gắn kết không thể tách rời, người Hàn nói: 말은 얻고 안장은 잃는다 được ngưa thì mất yên. Với người tiếp thu kém, chậm hiểu, người Việt dùng hình ảnh nước đổ lá khoai, nước đổ đầu vịt hay đàn gẩy tai trâu thì người Hàn dùng câu tục ngữ: 말귀에 염불하기다 nhu niệm Phật tai ngựa. Tiếng cười châm biếm đối với những người ngây ngô mua tích trữ hàng vô giá trị định kinh doanh: 말 뼈 사놓고 팔리기를 기다린다 mua xương ngưa tích trũ chò bán; cười người chậm chạp, để lỡ việc: 빌려온 말이 삼경이 되었다 mươn đươc ngưa thi đã canh ba...

Giáo huấn - truyền kinh nghiệm và cảnh báo là giá trị nổi bật của tục ngữ các dân tộc trên thế giới. Đó là những bài học về thái độ ứng xử, bài học đạo đức, đó là những kinh nghiệm lao động sản xuất... được người xưa đúc kết và truyền lại cho đời sau. Bên cạnh đó, phê phán, châm biếm là vũ khí đấu tranh giai cấp đối với những tiêu cực trong xã hội, là tiếng cười trào phúng đối với những thói xấu của con người. Tất cả đều hướng tới xây dựng một cuộc sống bình đẳng tốt đẹp hơn, con người yêu thương nhau hơn. Thiết nghĩ, đó cũng chính là cội nguồn của sức sống mãng liệt, tiềm tàng của một dân tộc chứa đựng trong kho tàng văn học dân gian này.

\section{Cuộc sống người dân Hàn qua tục ngữ có yếu tố chỉ con ngựa}

\subsection{Thân phận của người dân Hàn}

Trong xã hội phân chia giàu nghèo, có nhiều người sống rất thoải mái, dễ chịu: 가벼운 옷을 
입고 살찐 말을 탄다 măc áo mỏng, cuỡi ngựa béo. Cuộc sống thuận lợi được người Hàn ví với hình ảnh 말 타고 강건너기다 curơ $i$ ngưa qua sông: Nhờ đức lộc người khác mà sung sướng, qua sông cưỡi ngựa thì không bị ướt, lại nhanh. Tuy nhiên, trong cuộc sống, còn có rất nhiều người vất vả, đi lang thang khắp nơi: 말 갈 데 소 갈 데 다녔다 đi hết cả nooi ngựa đi, bò đến. Cuộc sống của người dân rất khó khăn, khổ cực, thường bị o ép, ví như: 말에 재갈 물린다 bắt ngựa ngậm hàm thiếc: Ngựa ngậm hàm thiếc thì không thể nói được, cũng không thể ăn được; có nhiều hoàn cảnh éo le vì tư tưởng trọng nam khinh nữ, chế độ đa thê: 한 마당에 암말만 둘이다 môt sân mà hai ngựa cái. Bên cạnh đó, những người tài bị bỏ quên, không được trọng dụng: 좋은 말이 마굿간에서 않고 있다 ngưa tốt nằm ôm trong chuồng ngựa. Người Việt có câu làm thân trâu ngựa chỉ sự vất vả của người lao động, luôn phải gánh vác những công việc nặng nhọc; đơn thương độc mã chỉ sự cô độc, không có người trợ giúp, đồng hành. Cũng như các dân tộc khác, người Hàn luôn mong muốn, khát khao có cuộc sống tự do: 매인 말은 항상 뛰고 싶어한다 ngưa bị buộc luôn muốn nhảy, 고삐 놓은 말이다 ngưa tháo dây cuong, 고삐 없는 말이다 ngura không cuong, 굴레 벗은 말 달아나듯 한다 chay nhu ngura tháo dây cuong, 굴레 벗은 말이다 nhu ngưa tháo cương... Tình yêu thương thể hiện qua tục ngữ, ví như: tình cảm đối với người và vật thân thuộc, yêu quí: 말은 콩을 그리워하다 nhu ngựa nhó đô̂; tình yêu quê hương đất nước tha thiết: 호마는 북풍을 그리워하다 $n g u x a$ hồ nhớ gió bắc: Con người sống tha phương thường nhớ về quê hương bản quán...

3.2. Thế giới quan, giá trị quan, phong tục tập quán

\subsubsection{Thế giới quan}

Người Hàn tin vào những dấu hiệu, điềm báo: 꿈에 흰 말을 타면 병을 얻는다 trong mo thấy cữ̛̃ ngựa bạch sẽ mắc bệnh: Câu này hàm ý cần thận trọng. Tuy nhiên, ngựa bạch là loài ngựa quí nên cũng được cho là dấu hiệu tốt, điềm lành: 아침에 흰 말을 보면 그날 돈이 생긴다 sáng dậy nếu gặp ngựa trắng hôm đó sẽ có tiền. Theo Song Jae Seun (1997: 139), người Hàn tin rằng 말굽이 묻혀야 잘 산다 phải chôn móng ngưa mói sống tốt: Ngày kết hôn, tuyết rơi thì phải đem chôn móng ngựa mà chàng trai vẫn cưỡi thì đôi vợ chồng mới sống tốt, hạnh phúc. Hay, 말 발이 젖어야 잘 산다 chân ngựa ướt móri sống tốt: Ngày kết hôn, trời phải mưa đủ để ướt chân con ngựa chú rể cưỡi thì đôi vợ chồng mới sống tốt. Bên cạnh đó, cũng có một số đơn vị tục ngữ tiếng Hàn thể hiện cái nhìn khá tiêu cực, đánh giá thấp về ngựa: coi chân ngựa là xấu, như một khiếm khuyết cần che giấu: 말 다리가 드러났다 lộ chân ngựa; cho rằng con gái tuổi ngựa vất vả: 말띠 가진 여자는 팔자가 세다 con gái tuổi ngựa cao số; quan niệm mặt dài thì xấu: 말 상이다 (dài) nhu mặt ngưa. Tuy nhiên, thịt ngựa được dùng như bài thuốc hữu hiệu trị chứng trúng gió, co giật: 말고기는 경기 약이다 thịt ngựa là thuốc kinh phong.

Người Hàn coi trọng cuộc sống: 말 똥에 굴러도 이승이 낫다 dù có vấy phân ngựa nhung trần thế vẫn tốt: Dù có khổ cực bao nhiêu thì sự sống vẫn quí giá hơn cái chết. Đời người 100 năm nhưng cũng chỉ như trong chớp mắt, nếu như người Hàn dùng hình ảnh: 인생 백년이 말 달리듯 한다 trăm năm cõi người nhu ngựa chạy thì người Việt cũng dùng câu: đời người nhu bóng câu qua cưa sổ. Dân tộc Hàn cho rằng, những mối nhân duyên tốt đẹp sẽ tạo nên kì tích: 준마도 장수를 만나야 하늘을 난다 tuấn mã phải gặp tướng giỏi mói bay lên trời, và ngược lại, nếu không gặp được người cặp đôi với mình thì sẽ hoài phí cả cuộc đời: 준마라도 주인을 못 만나면 삵말로 늙는다 tuấn mã không gặp được chủ hay thì già với kiếp ngưa cho thuê. Những qui luật cuộc đời về thời vận và quan hệ nhân gian cũng thể hiện khá rõ nhân sinh quan của người Hàn. Người Việt hay nói: con chị nó đi thì con dì nó lớn, người Hàn 
dùng hình ảnh: 큰 말이 나가면 작은 말이 큰 말 노릇한다 ngựa lón đi thì ngưa nhỏ thế chố, làm việc của ngưa lón. Cả người Hàn và người Việt đều dùng hình ảnh: ngư tầm ngưu, mã tầm $m \tilde{a}=$ 말 우는 데 말 가고 소 우는 데 소 간다 ngựa đến nơi ngựa hí, bò đến nơi bò kêu: Người ngoan hiền thân với người ngoan hiền, người ác chơi với người ác...

\subsubsection{Giá trị quan}

Người Hàn cho rằng, vật có giá trị cũng cần phải được dùng đúng lúc, trao đúng người, nếu không, khó tránh khỏi hiện tượng: 거지가 말 얻은 격이다 vô dụng nhu ăn mày dược ngưa . Quan niệm về giàu và nghèo của người nông dân Hàn khá cụ thể: 마소가 많으면 부자요, 자식이 많으면 거지다 nhà nhiều bò ngưa thì giàu, nhà đông con thì nghèo. Xã hội phân chia giai cấp, phân biệt giàu nghèo nên thang giá trị cũng được xác định theo tiêu chuẩn đó, cách đối xử cũng có sự khác biệt rõ rệt: 말없는 양반은 소를 탄다 qui tộc không nói (là quí tộc) thì cuõoi bò: Không nói rõ thân phận thì không ai biết là quí tộc, kết quả là chịu đối xử như thứ dân, chỉ được cưỡi bò chứ không phải là cưỡi ngựa. Người Hàn sống lạc quan bởi họ có triết lí nhân sinh thật giản dị mà sâu sắc: 말 탄 놈도 서울이요, 소 탄 놈도 서울이요 người cuõi ngưa cunng đến Seoul, người cữoi bò cũng đến Seoul: Trên đường đời, sẽ có người đến đích sớm, có người đến muộn hơn nhưng cuối cùng đều tụ chung một điểm đích, dù thời gian hay tốc độ nhanh chậm, con đường dài ngắn mỗi người đi không giống nhau...

Quan niệm của người Hàn về trách nhiệm, lương tâm cũng được thể hiện qua tục ngữ: 말도 부끄러우면 땀을 흘린다 ngựa xấu hổ cũng toát mồ hôi. Nhận thức về mối quan hệ giữa cái chung và cái riêng, cái toàn thể và cái bộ phận, người Hàn dùng hình ảnh: 말이 뛰면 털도 뛴다 ngưa chay thì lông cũng chạy (chuyển động): đất nước khó khăn thì dân cũng đói khổ. Với ý nghĩa này, người Việt dùng hình ảnh: nước nổi thi thuyền cũng nổi. Chịu ảnh hưởng của tư tưởng Phật giáo, người Hàn nhận thức rõ quan niệm nhân quả: 소금 먹는 말이 물 찾는다 ngưa ăn muối sẽ tìm nước uống: Nếu có nhân (nguyên nhân) nào sẽ dẫn tới quả (kết quả) tương ứng. Người Việt dùng cách nói thẳng, trực tiếp hơn: Đời cha ăn mặn, đời con khát niớc... Trong quá khứ, đặc biệt là trong hoàng tộc hoặc các gia đình quyền quí ở Hàn Quốc vẫn thường có hôn nhân cận huyết thống. Tuy nhiên, người dân Hàn thể hiện quan điểm của mình qua tục ngữ như sau: 말도 상피를 본다 ngưa cũng phải để ý đến quan hệ ho hàng, 말도 칠판촌은 가린다 ngưa cũng phải tránh cận hôn đến 7- 8 đời (Song Jae Seun, 1997: 141). Bên cạnh đó, trong tục ngữ tuy không thể hiện rõ nhưng cũng có đơn vị thể hiện thái độ coi thường, bất bình đẳng với nữ giới: 처녀들은 말 방귀만 뀌어도 웃는다 tui con gái thì ngụa đánh rắm cũng cười...

\subsubsection{Phong tục tập quán}

Qua các đơn vị tục ngữ có yếu tố chỉ ngựa, có thể thấy vài nét văn hóa khá độc đáo của người Hàn: 말 머리에 태기 든다 bắt đầu thai ki ở đầu ngụa: Trong văn hóa truyền thống, khi cô dâu đi lấy chồng thường cưỡi ngựa. Câu tục ngữ chỉ công việc tiến hành quá nhanh, giống như cô dâu đi lấy chồng đã có thai. Câu 말 탄 장가다 cuơoi ngựa đi lấy $v o^{\prime}$ nói đến tập tục xưa, chàng trai thường cưỡi ngựa trong ngày lễ kết hôn, đến đón cô dâu. Tín ngưỡng dân gian của người Hàn trong tục ngữ ngựa thể hiện ở niềm tin vào sức mạnh trừ tà của hình tượng hổ và rồng: 말 병 예방에 는 마굿간에 여호 여룡이라는 부적을 써붙인다 dán bùa chú viết nhu hổ nhu long ở chuồng ngưa phòng bệnh cho ngưa; 말 병 예방에는 호랑이 뼈를 목에 걸어준다 đeo xương hổ vào cổ ngưa để phòng bệnh cho ngựa... Triết lí nhân sinh quan Phật giáo: sinh, lão, bệnh, tử cũng thể hiện khá rõ trong tục ngữ có yếu tố chỉ con ngựa. Từ việc những chú ngựa con ra đời theo qui luật tự nhiên, 
sống và lớn lên cùng bầy đàn, trở thành những chiến bình thiên lí mã, long mã hay những chú ngựa thồ, rồi trở về già ốm yếu, bệnh tật, xa rời thế giới với sự mong đợi của những người thợ da thuộc... Đó cũng chính là những giai đoạn của cuộc đời một con người. Lên xe xuống ngựa, sông có khúc, người có lúc là các câu tục ngữ người Việt chỉ sự thăng trầm của cuộc đời. Người Việt cũng liên tưởng thời gian trôi nhanh như bóng câu qua cửa; sự thay đổi về phe phái thể hiện bằng câu thay ngựa đổi chủ... Ngoài ra, một số điều kiêng kị của dân gian cũng được truyền lại trong tục ngữ: 말이 새끼 난 지 이레 안에 간장을 남에게 주면 어미젖이 마른다 ngưa sinh con trong vòng 7 ngày, nếu cho người khác nước mắm thì me ngưa sẽ mất sũa. 아이 밴 여자가 말 고삐를 넘으면 아이를 열두 달 만에 낳는다 $p h u$ nũ có bầu nếu buớc qua dây cuơng ngựa thì mang thai đủ 12 tháng mới sinh.

Ngoài ra, dấu ấn địa lí - văn hóa của một số vùng miền trên bán đảo Hàn cũng được thể hiện qua tục ngữ, có thể đơn cử một vài ví dụ sau đây: i) 금산 체장수 죽은 말 지키듯 한다 đơi nhu chejangsu Geumsan chò ngưa chêt. Geumsan, Cheonllado 전라도 (nay là Chungnam 충남) là nơi sản xuất các sản phẩm từ lông đuôi ngựa của Hàn Quốc; ii) 닫는 말 채질한다고 경상도를 당일 갈까? thúc ngưa đang phi hết sức liệu quất roi có đến được Gyeongsangdo trong ngày không? Có thể thấy Gyeongsangdo là nơi khá xa, không thể tới trong ngày dù có ngựa tốt; iii) 말새끼는 시골로 보내고 사람 새끼는 서울로 보내라 ngựa con gửi về nông thôn, trẻ con gửi lên Seoul. Seoul là nơi đất lành, phát triển, tốt cho việc học hành, giáo dục của trẻ. Hay 말은 나면 제주도로 보내고 사람은 나면 서울로 보낸다 ngựa đẻ gửi đến đảo Cheju, nguời sinh cho đến Seoul: Đảo Cheju tốt cho ngựa, Seoul tốt cho con trẻ; iv) 말 탄 양반 청태 도적이라 qui tộc cuõ̃i ngựa trộm rong biển (tục ngữ Cheju): Cheju là đảo với bốn bề là biển, rong biển là sản vật quí của nơi này; v) Mùa xuân trên bán đảo Hàn, thời tiết hanh khô khiến da dẻ nứt nẻ: 봄바람에 말 씹도 터진다 gió xuân khiến âm hộ ngưa cũng nưt toác. 봄에는 생말 가죽이 마른다 mùa xuân da ngưa sống cũng $k h o ̂$. Tuy nhiên, mùa xuân cũng là mùa mọi vật hồi sinh, có sức sống mãnh liệt: 봄이면 삼년 묵은 말가죽에도 오롱조롱 소리가 난다 xuân đến, da ngựa khô ba năm cũng phát ra tiếng động... Tuy chỉ là một vài nét chấm phá về địa lí vùng miền nhưng qua tục ngữ có yếu tố chỉ con ngựa, ta có thể hiểu thêm về đất nước và con người Hàn Quốc.

Như vậy, qua tục ngữ có yếu tố chỉ con ngựa, ta có thể tìm thấy ít nhiều những dấu ấn lịch sử, văn hóa, xã hội của một dân tộc; có thể nhận biết được phương thức tư duy, tìm hiểu về giá trị quan, nhân sinh quan, thế giới quan, phong tục tập quán của dân tộc Hàn, đặc điểm địa lí vùng miền của Hàn Quốc.

\section{Kết luận}

Với những đặc tính đáng quí, ngựa là hình ảnh của sự trung thành, tận tụy, thanh nhã mà hào hùng. Mã đáo thành công là câu chúc thành công, may mắn người Việt hay dùng. Hình ảnh con ngựa trong tục ngữ cũng chính là tấm gương phản chiếu của cuộc đời con người với quá trình sinh lão bệnh tư. Tục ngữ tiếng Hàn có yếu tố chỉ con ngựa hàm chứa giá trị giáo huấn, đề cao những giá trị tốt đẹp, chuyển tải những bài học kinh nghiệm đối nhân xử thế, kinh nghiệm làm ăn, tu thân. Giá trị phê phán cũng là một mặt không thể thiếu, thể hiện quan điểm rõ ràng của dân tộc Hàn đối với cái ác, cái xấu trong xã hội và con người. Qua tục ngữ có yếu tố chỉ con ngựa, cũng có thể thấy một phần đời sống tinh thần và vật chất, những dấu ấn văn hóa mang đậm nét dân gian, truyền thống của dân tộc Hàn. Vài nét phác họa, liên hệ với tục ngữ tiếng Việt cũng cho thấy, có không ít những nét tương đồng trong văn hóa của hai dân tộc. 


\section{Tài liệu tham khảo}

\section{Tiếng Việt}

Nguyễn Thùy Dương (2013). Một số tín hiệu thẩm mỹ trong thành ngũu, tục ngũu tiếng Hàn. Luận văn Thạc sĩ. Trường Đại học Khoa học xã hội và nhân văn Đại học Quốc gia Hà Nội.

Nguyễn Thị Hồng Hạnh (2013). Văn hóa ưng xủ của người Hàn qua thành ngũu, tuc ngũ (so sánh với Việt Nam). Luận văn Thạc sĩ. Trường Đại học Khoa học xã hội và nhân văn - Đại học Quốc gia thành phố Hồ Chí Minh.

Lê Thị Hương (2015). Thành ngũu, tục ngũ Hàn Quốc nói về động vật và thực vật (một vài so sánh với Việt Nam). Luận văn Thạc sĩ. Trường Đại học Khoa học xã hội và nhân văn - Đại học Quốc gia Hà Nội

Nguyễn Văn Nở (2008). Biểu trung trong tục ngũu người Việt. Hà Nội: Nxb Đại học Quốc gia Hà Nội.

Vũ Ngọc Phan (2008). Tục ngũu, ca dao, dân ca Việt Nam. Hà Nội: Nxb Văn học.

Trần Văn Tiếng (2006). So sánh một số đặc điểm cú phápngũ nghĩa của tục ngũ tiếng Việt và tiếng Hàn. Luận án Tiên sĩ. Đại học Quốc gia thành phố Hồ Chí Minh.

Lê Thị Thương (2009). Nghiên cứu đối chiếu thành ngũ Hàn - Việt có thành tố cấu tạo là tên gọi động vật tù góc nhìn ngôn ngũ - văn hoá. Luận văn Thạc sĩ. Trường Đại học Khoa học xã hội và nhân văn - Đại học Quốc gia Hà Nội.

Hoàng Thị Yến, Nguyễn Thùy Dương (2016). Nghiên cứu tục ngữ tiếng Hàn có yếu tố chỉ con hổ. Tạp chí Hàn Quốc, 01 (15), tr. 61-76.

Hoàng Thị Yến (2017). Tục ngữ tiếng Hàn có yếu tố chỉ con mèo (liên hệ với tiếng Việt). Nghiên cưu Nước ngoài, 33(2), tr.155-167.

\section{Tiếng Hàn}

Byambachereng Battolga (2012). Nghiên cúu so sánh tục ngũu Hàn Quốc và Mông Cổ: trọng tâm là tục ngũ có yếu tố chỉ ngựa. Đại học Gongjoo. Hàn Quốc. Luận văn Thạc sĩ.

뱜바체렝 받돌가 (2012). 한국과 몽골의 속담 비교 연구: ‘말 馬' 관련 속담을 중심으로. 공주대학교. 석사 논문.

Ho Nyung Nyung (2011). Nghiên cứu so sánh tục ngũ Hàn - Trung có yếu tố chỉ ngụa. Đại học Hoseo. Luận văn Thạc sĩ.

호녕녕 (2011). 한국과 중국의 말 (馬) 관련 속담 비교 연구. 호서 대학교. 석사 논문

Jang Jae Hwan (2009). So sánh tục ngũ động vật Nhật - Hàn: trọng tâm là tục ngũ có yếu tố chỉ ngụa và chó. Đại học Danguk. Hàn Quốc. Luận văn Thạc sĩ.

장재환 (2009). 일. 한 동물 속담에 관한 비교. 고찰: '말'과 '개'에 관한 속담을 중심으로. 단국대학교. 석사논문

Kim Myung Hwa (2011). Nghiên cúu so sánh tục ngũ động vật 12 con giáp Hàn - Trung. Đại học Dongjoo. Hàn Quốc. Luận văn Thạc sĩ.

김명화 (2011). 한-중 12 지신 동물 속담 비교 연구. 동주 대학교. 석사논문.

Song Jae Seun (1997). Tù điển tục ngũu động vật. Nxb Dongmunseon.

송재선 (1997). 동물속담 사전. 東文選.

\title{
CHARACTERISTICS OF KOREAN CULTURE IN HORSE-RELATED PROVERBS
}

\author{
Hoang Thi Yen \\ Faculty of Korean Language and Culture, VNU University of Languages and International Studies, \\ Pham Van Dong, Cau Giay, Hanoi, Vietnam
}

\begin{abstract}
This paper combines descriptive, analytical and synthetic methods in exploring 361 Korean proverbs containing or relating to the horse. The study finds that the horse is realistically depicted in Korean proverbs as a symbol of human life. Symbolic values of Korean horse-related proverbs are revealed through the appreciation of Truth, Goodness, and Beauty, educational maxims and experience about life and social relationships. Horse-related proverbs also vividly demonstrate strong yet sophisticated criticism against evils and negative features as well as satire of human vices. Korean people's material and spiritual life and cultural patterns imbued with their worldview are densely packed in horse-related proverbs. A comparison with Vietnamese proverbs, plenty of which also contain the horse, enlightens us about the various similarities between the two languages.
\end{abstract}

Keywords: Korean proverbs, horse, symbolic value 